\title{
The Impact and Dilemma of Unfunded Mandates Confronting Local Government in South Africa: A Comparative Analysis
}

\author{
M. Basdeo
}

Abstract

ocal government has emerged from a Lprolonged transition to face a second generation of challenges, namely unfunded mandates. Compliance with the current financial management system is a constant challenge for local government. To complicate matters local government is challenged by the dilemma of unfunded mandates which are an extreme manifestation of the phenomenon of governing from the centre. National government through various strategies imposes national mandates on provincial and local government at the expense of the latter. The incidence of unfunded mandate reflects a power hierarchy. Unfunded mandates are generally a significant indicator of the relative weakness of national government because it is often local government occupying constitutionally and politically the weakest position in the hierarchy that is burdened with new responsibilities. In decentralised and federal government systems, provincial/state and local governments object to unfunded mandates because they shrink their policy space, limit their expenditure choices and ultimately local government's accountability to their electorates. Further, these systems of governance establish a hierarchy of authority that creates notions of self-rule by national government. Unfunded mandates reflect systemic weaknesses of decentralised or federal allocation of powers and functions. Although there are principled objections, unfunded mandates remain constitutional. Given the wide incidence of unfunded mandates the critical question arises as to how in a decentralised system, one level of government can impose mandates with cost implications on another. How is it constitutionally justifiable?

Keywords: Local Government, Unfunded Mandates, Service Delivery, South Africa 


\section{INTRODUCTION}

The confusion and challenges emanating from unfunded mandates are shared by most decentralised and federal systems of government. Unfunded mandates are a characteristic arising from the division of powers between two levels of government. The problem is aggravated when a third level of government is added, namely local government. This leads to concurrency of powers and functions, which causes an element of confusion about who does what. Since their inception, some municipalities have raised the issue that they are compelled to perform functions which are not allocated to them in terms of the Constitution and legislation on powers and functions (Financial and Fiscal Commission: 2012/13 Submission for the Division of Revenue). Local government has also pointed out that they face unfunded or underfunded mandates as a result of policy decisions made at national government level. These decisions have financial implications, but come without the necessary funding for their implementation. Essential legal procedures need to be followed when assigning and delegating additional functions or powers, to other spheres of government. In a number of functional areas there are no legal basis for local government's activities. A clear example of the latter relates to the functioning of libraries.

The argument in this paper is developed in the context of different federal type countries that have sought to deal with unfunded mandates, namely, the United States of America and Australia. Despite constitutional differences remarkably similar responses to unfunded mandates are encountered. This paper argues that the approach for curbing or containing unfunded mandates are two-fold, namely, radical intervention to impose a clear prohibition on the imposition of unfunded mandates similar to that done by the United States of America and Australia, and the more general approach is to admonish the transferring legislature or authority to stop, evaluate and consider before imposing a mandate.

\section{CONSTITUTIONAL AND LEGISLATIVE FRAMEWORK FOR LOCAL GOVERNMENT}

The constitutional objectives for local government are enshrined in section 152 of the Constitution of the Republic of South Africa, 1996 (hereafter referred to as the Constitution). Local government must be developmental in purpose and pursue the following objectives: 
a) to provide democratic and accountable government for local communities

b) to ensure the provision of services to communities in a sustainable manner

c) to promote social and economic development

d) to promote a safe and healthy environment, and

e) to encourage the involvement of communities and community organisations in the matters of local government.

When the first democratic elections were held in South Africa in April 1994, local government was a racist institution, giving effect to the spatial separation of blacks and whites (Steytler, 2005:183). The black community was further divided into African, Coloured and Indian, each with their own local authority. These racial divisions meant massive inequality in services. The white communities were well serviced while the black communities received inferior or no services at all. Local government was the lowest tier of government in a strict hierarchical structure. Municipalities, as creatures of statute derived their powers from national and provincial government and served largely as their administrative arm. Local government comprised of small, fractured municipalities organised along racial lines, giving effect to the policies of the highly centralised apartheid state. The transformation of local government was directed at eliminating the racial basis of government and making it a vehicle for the integration of society and for the equitable distribution of resources. Fundamental to this approach was entrenchment of local government in the 1996 Constitution, as a fully fledged sphere of government. While the future shape, form and existence of provinces are debated, local government is viewed as an indispensable feature of our state structure. This paper stresses that, whether South Africa will become a centralised state or will retain some federal features in its state organisation, depends largely on the entrenchment of the practice of local self-governance. The trend is to increase the role of local authorities in the provision of services. Local government is the engine for growth and development.

Contrary to the race-based local government institutions of the pre-1994 era, which were creatures of statute and under the direct control of both the national government and provincial administrations, the 1996 Constitution has enhanced the status of local government as a distinctive sphere of government, together with national and provincial government. In Chapter 3 of the Constitution entitled Co-operative Government section 40 provides that in the Republic, government is constituted as national, provincial and local spheres of 
government, which are distinctive, interdependent and interrelated. Section 151 of the Constitution provides that the local sphere consists of municipalities which must be established for the whole of the territory of the Republic and that a municipality has the right to govern, on its own initiative, the local government affairs of its community, as provided for in the Constitution. Section 151 also provides further [ 51 ] that the national or provincial government may not compromise or impede a municipality's ability to exercise its powers or perform its functions.

Local government in South Africa has contributed to the achievement of a number of significant social and economic development advances since the birth of the new democratic municipal dispensation in December 2000 (Department of Cooperative Governance and Traditional Affairs, 2009:3). However, despite the valuable role and contribution of local government in South Africa's newfound democracy key elements of the local government system are showing signs of distress. The current local government system has been in place for eleven years and is still in its formative development stages. While the future demographics of the provinces are scrutinised and debated it is accepted that local government is an indispensable feature of the South African governance structure. The only and rather critical question concerns its nature, status and extent as a self-governing institution (Steytler, 2005:183). With the increased status and role of local government, intergovernmental relations between the three levels of government have not only become more complex, but also critical for the demarcation of responsibilities and effective co-operation in service delivery. The White Paper on Local Government, 1998 defines developmental local government as the type of local government committed to working with citizens and groups within the community to find sustainable ways to meet their social, economic and material needs and improve the quality of their lives. In terms of its developmental role local government is required to put in place a range of strategic interventions, secure investment, encourage growth and deal with issues of social exclusion and poverty (Nel and Binns, 2003:165).

\section{THE DEVELOPMENTAL ROLE AND COMPETENCIES OF LOCAL GOVERNMENT}

The White Paper on Local Government, 1998 defines developmental local government as the type of local government committed to working with citizens and groups within the community to find sustainable ways to meet their social, economic and material needs and improve the quality of their lives. In terms of its developmental role local government is required to put in place a range of 
strategic interventions, secure investment, encourage growth and deal with issues of social exclusion and poverty (Nel and Binns, 2003:165).

The constitutional allocation of competencies to local government assumes various approaches. A common approach is to itemise a list of functional areas that fall within the parameters of municipalities. Section 156(1) of the Constitution demarcates the concurrent and exclusive competencies of the provinces into Parts $A$ and $B$, with the latter listing the functional areas of municipalities. However, even in cases where the powers of local government are specifically listed, it seldom means that municipalities have exclusive jurisdiction over the listed functional areas. They are usually burdened with national or provincial regulatory frameworks. The various ways in which local government competencies are defined all produce some level of overlap between the functions of the state or province and local government.

The following forms of overlapping and concurrency can be distinguished:

1) Managerial overlaps: In practice common competencies arise where local government's powers are exercised within regulatory frameworks set by federal or state governments (Steytler, 2005:276). In respect of the same functional areas, both spheres of government have authority, even though the state government's powers should only be regulatory. The Constitution provides that national and provincial government may regulate the exercise by municipalities of their powers in the listed functional areas. In terms of section 157(7) of the Constitution, both national and provincial governments have the legislative authority to monitor and ensure the effective performance by municipalities of their functions by regulating their executive authority. However, in terms of sections 156(3) and 151(1), such regulation is subject to national or provincial government not compromising or impeding a municipality's ability to govern or exercise its powers. Consequently, an element of superficiality is attached to the latter.

2) Participatory common competencies: Local government is expected to work alongside and assist the other levels of government in a specific functional area. Despite the allocation of competencies being distinct in specific cases, judicial interpretation can sometimes also impose participatory functions. For example, in Government of RSA v Grootboom 2000 (11) BCLR 883 (CC), the court maintained that the responsibility of government to provide shelter as a minimum standard, fell on all three spheres of government, despite the fact that housing as a competency does not fall within local government's domain of competencies, but 
which in terms of Schedule 4A of the Constitution forms part of national and provincial governments' list of concurrent competencies. The Nigerian Constitution of 1999 also provides a good example of participatory common competencies. In article 7(2), it provides that the functions of local authorities shall include participation in state functions such as the provision of education and health services.

3) Specific concurrent competencies: The most typical common competencies are where specific functional areas are concurrently given to the state or province and local government. This approach is not unique to the allocation of local government powers, but is also utilised in the distribution of powers between federal or national government and states or provinces. Section 44(1) and Schedule 4 of the Constitution contains a list of concurrent competencies. The constitutions of India and Brazil also contain a list of concurrent competencies similar to South Africa.

4) Vaguely defined competencies: In certain instances, despite competencies being exclusively mandated to local government, vague definitions of such powers result in overlapping competencies in practice. For example, in South Africa functional areas overlap between provincial and local government in the areas of tourism, health, transport, trade, sports, roads and recreation. There is no a priori answer to the question of where a local government ends and a state or provincial government commences (Steytler, 2005:277). When does a health service stop being a local government concern and become a provincial or National Health Service priority? Without clearly defined answers there is an inevitable overlap in competency pertaining to administration of health services.

\section{THE CHALLENGE OF DEFINING UNFUNDED MANDATES}

The concern about unfunded mandates and the nomenclature used to define and refer to unfunded mandates is varied in federal and decentralised systems. Unfunded mandates assume various names in different countries. In Australia it is referred to as 'cost shifting' (Sansom, 2009:20), and in Canada it is referred to as 'service responsibility downloading' (McMillan, 2006:52), while in South Africa and in the United States of America, it is commonly referred to as 'unfunded mandates'. Definitions of unfunded mandates generally emphasise costs and 
shifts in responsibility. A broader definition is proffered by state and local governments who are subject to federal intervention, while a more narrow definition is advanced by federal governments (Steytler et al., 2011: 1).

In South Africa, a restricted definition was adopted, restricting it to the transfer of functions. The concept of unfunded mandates is further restricted to local government because of its limited application to provinces (Steytler et al., 2011: 4). To deal with unfunded mandates and the constraints they place on local government, the Local Government: Municipal Systems Act of 2000 was amended in 2001 to include provisions to regulate the transfer of functions to local government. The 2003 amendments to the Municipal Systems Act, 2000 (hereafter referred to as the Municipal Systems Act) specifically, sections 9 and 10 aims to prevent unfunded mandates flowing from legislative assignments and the 2003 amendments to the Financial and Fiscal Commission Act of 1997 requires organs of state to assess the financial and fiscal implications, and to obtain the Commission's recommendations, before functions that are assigned to other organs of state in another sphere of government becomes law. The Municipal Systems Act, however, does not accurately define that which it intends to prevent. The Municipal Systems Act prescribes procedural requisites that apply to legislative or executive processes that assign a 'function or power' to local government.

Broadly unfunded mandates refer to situations in which sub-national governments are legally mandated in terms of the Constitution or in terms of policy pronouncement to undertake specific functions, but do not receive funds from nationally raised revenues in order to perform these functions (Khumalo \& Mokate, 2007:271). A narrow definition confines "unfunded mandates" to the transfer of new functions not constitutionally assigned to provincial or local government. Section 10A of the Municipal Systems Act contains what appears to be closest to a definition of "unfunded mandate" where the transferring organ of state is instructed to ensure funding and capacity building to accompany assignments that impose a duty; fall outside of the municipality's original constitutional powers, and have financial implications. While the definition clearly includes the explicit imposition of new functions on local government it does not extend to the reduction of funding or revenue-generating powers, the regulation of compliance requirements or the filling of service delivery gaps, left by national and provincial governments (Steytler et al., 2011: 4).

Further South Africa's progressive Bill of Rights with its resource-intensive socio-economic rights introduces a further complication that eludes the definition of the Municipal Systems Act. The critical question is whether fundamental rights, such as the right to primary health care and the right of 
access to housing result in unfunded mandates. National and provincial governments are constitutionally responsible for these functions, but local government is often the first tangible point of contact where citizens claim their constitutional rights. This definitional aspect may be solved by the courts which have generally voiced contempt at intergovernmental controversies over the state's responsibility to care for the destitute (Steytler, et al., 2011: 4).

The United States Unfunded Mandate Reform Act, 1995 (hereafter referred to as UMRA) stipulates a mandate arises from an enforceable duty imposed on states, local authorities, tribal authorities or the private sector, or from a reduction or elimination of prior funding for compliance with such duty. An unfunded mandate does not arise when the duty is a condition of federal assistance or from participation in a voluntary federal programme. In terms of UMRA an unfunded mandate must be accompanied by costs. In determining costs only direct costs are taken into consideration. Further, a cost also arises when the federal appropriations are reduced or eliminated for a mandate previously imposed and funded. The objective of UMRA was not to displace or eliminate unfunded mandates, but rather to promote decision-making by compelling the Congress and Federal agencies to consider the cost of imposing mandates on states, local and tribal governments, and the private sector.

In Australia the federal House of Representatives Standing Committee on Economics, Finance and Public Administration found difficulty in formulating a consensual view of unfunded mandates, or cost shifting (Steytler et al., 2011: 4). In Australia local governments defined the concept "unfunded mandates" very broadly. The Australian Local Government Association identified at least three forms of cost shifting/unfunded mandates. The first is where local authorities are required to provide services that previously were performed by other spheres of government. The second is where the federal or state governments require local government to provide concessions or rebates on their revenue resources without compensation. The third is where the supervising governments require that local government undertake cost compliance activities.

Taking cognisance of the challenges in defining unfunded mandates, it is apparent that unfunded mandates will always be a contested terrain between the different levels of government. While local governments strive for a broad concept, national government endeavours to narrow the ambit of unfunded mandates. As a result of the inevitable consequence of a lack of consensus in defining unfunded mandates, it is apparent that it is difficult to agree on the extent and cost of unfunded mandates. 


\section{THE CONSTITUTIONAL AND LEGISLATIVE CHALLENGES OF UNFUNDED MANDATES}

The Constitution of the Republic of South Africa, 1996 (hereafter referred to as the Constitution), defines the functions and relationships of the different spheres of government in South Africa. With regard to the local sphere of government both the national and provincial governments may impose mandates on local government. Provinces have concurrent powers in functional areas listed in Schedule 4 (shared with the national government) and exclusive powers with regard to Schedule 5 matters. Municipalities have powers in respect of the functional areas listed in Schedule $4 \mathrm{~B}$ and $5 \mathrm{~B}$. All residual matters fall under the jurisdiction of the national government. Provincial legislatures may also regulate the functional areas pertaining to the list of competencies in Schedule 5B of the Constitution. Both national and provincial legislatures may assign any of its legislative competencies to local government. The latter is also applicable to the assignment of executive powers, but in such an instance, the agreement of the municipality concerned must be obtained.

In a highly centralised federal system, such as South Africa, a clear division of powers and functions is neither provided nor envisaged in the Constitution (Steytler et al., 2011: 8). Subject to a qualified override the national parliament may legislate freely at will with regard to the list of concurrent functions in Schedule 4 in the provincial sphere of government. In the case of exclusive provincial competencies listed is Schedule 5, the national parliament may still intervene in listed circumstances. There are thus very few limitations on the national parliament to impose mandates on the provinces. It is rather contradictory and ambiguous as provinces do not have their own sources of revenue which could fund additional functions. With $97 \%$ of their income derived from national transfers, there is little incentive for national government to burden them with additional tasks, the payment for which would come in any event from the national government (Steytler et al., 2011: 8).

The Constitution draws a link between the functions of the different spheres of government and the funding to perform that mandate. Section 227(1)(a) of the Constitution provides that: "Local government and each province is entitled to an equitable share of revenue raised nationally to enable it to provide basic services and perform functions allocated to it." The entitlement to an equitable share is thus linked to basic services to be provided.

The following are some of the examples of the existence of unfunded mandates in South Africa (Financial and Fiscal Commission: 2012/13 Submission for the Division of Revenue, 2011:86): 
i. Health service (primary health care): Municipalities often cite primary health care as an unfunded mandate. The National Health Council in 2005 resolved that primary health care would be a provincial responsibility, and municipal health services would remain a municipal responsibility. In terms of the 2005 resolution, municipal clinics were to be transferred to the provincial health structures in a process known as "provincialisation". However, in 2007 the South African Local Government Association (SALGA) advised all municipalities to halt all further transfers of primary health care to the provincial government until clarity had been reached on what constitutes primary health care. Since then no primary health care services have been provincialised from any metropolitan municipality in South Africa. The Constitution lists "Municipal health services" as a Schedule 4B function. Municipalities that provide primary health services must adhere to national standards which entail, inter alia, the provision of free health services. Municipalities thus feel compelled to provide this service and to uphold a legally prescribed standard in doing so, which inadvertently comes at a cost. Municipalities that perform primary health services do so in terms of agency agreements which generally provide for inadequate funding arrangements.

ii. Libraries other than national libraries are a Schedule 5A functional area that falls within the exclusive legislative competence of a province. Municipalities have no comparable competence. As an exclusive provincial competence, provinces are active in this functional area, but only to a limited degree. There has been no legislative or executive assignment by the provinces of the library function to municipalities. However, until the Constitution became operational, libraries were a local government function, and most public libraries are currently still administered and funded by municipalities. For example, in the Western Cape there are 148 library sites in non-metropolitan areas, and 105 in the City of Cape Town. The Province administers libraries in only three municipalities which were apparently due to the refusal of the municipalities to continue with the library function in 2000. The critical question is then why do municipalities continue to perform a function that is not legally theirs. The answer is situational. It is socially and politically unacceptable for municipalities to close their libraries knowing that the provincial government may not take over or provide adequate compensation for this function. 


\section{FRAMEWORK FOR MANAGING UNFUNDED MANDATES}

It is clear that unfunded mandates exist between the different spheres of government. According to the Financial and Fiscal Commission: 2012/13 Submission for the Division of Revenue (2011: 90), a total of six metros have spent an additional amount of R3,819 billion in 2008/09 and R4,194 billion in $2009 / 10$ in the provision of existing unfunded mandates. To date there has been varied responses to unfunded mandates. In certain instances, the prohibitions of unfunded mandates have been adopted as a control measure. In other instances unfunded mandates have been highlighted as a political issue.

i. The government should take steps to ensure that all mandates have a legal basis (Financial and Fiscal Commission: 2012/13 Submission for the Division of Revenue 2011:91). The functions performed by each sphere of government should have a secure legal footing. Performing functions falling outside the mandate of local government impinges upon the lawfulness of their budgets, although their expenditure is not necessarily illegal. Further, the government should undertake a review of the extent of compliance with legal procedures for the assignment and delegation of functions, as stipulated in the Intergovernmental Fiscal Relations Act, the Financial and Fiscal Commission Act, the Division of Revenue Act and the Local Government Municipal Systems Act. More specifically, it is recommended that compliance with the following legal requirements should be assessed:

ii. The financial and fiscal implications of a function shift on the sphere of government or organ of state. The organ of state initiating a general assignment must provide these implications to the Financial and Fiscal Commission for its recommendations to the Minister of Finance as prescribed by section 3 of the Financial and Fiscal Commission Act.

iii. All resources associated with delivering a service associated with a function to be shifted are transferred. These should include current assets, budgets and all future resources. There should be evidence of a decision taken by the executing authority of the assigning or delegating department or organ of state that this is acknowledged and pledged.

According to Zimmerman (1995: 88), during the late nineteen seventies and early nineteen eighties, and again in the early nineteen nineties in the United 
States fifteen states amended their constitutions to curb unfunded mandates. The following methods were employed:

a) Prohibiting the imposition of some or all types of state mandates;

b) Requiring reimbursements of all or part of the costs associated with the mandates;

c) Delaying the implementation date of a mandate;

d) Authorising local governments to ignore an unfunded mandate;

e) Requiring a two thirds vote of each house of the state legislature for imposing a mandate;

f) Authorising the governor of a state to suspend a mandate; or

g) Providing that the implementation date of a mandate is delayed.

In addition to the employment of legal measures in managing unfunded mandates, the intergovernmental political approach has been adopted in the United States of America at federal level, South Africa and Australia. In the United States, the objective of UMRA was not to disband unfunded mandates but to promote decision-making by compelling the Congress and federal agencies to consider the cost of imposing mandates on states and local and tribal governments. The latter approach was called the 'stop, look and listen' approach to mandates (Posner, 1997:53). The key instrument in managing an unfunded mandate is to provide Congress with information about the cost impact that federal legislation may have. The key player in this process is the Congressional Budget Office (CBO). The Congressional Budget Office must prepare so-called mandate statements which must identify and describe federal mandates in proposed legislation, quantify, where possible, the direct cost of such mandates. Further, the Congressional Budget Office must provide an estimate of anticipated indirect costs, and secondary effects. The procedural device provided by UMRA is that a law that creates an unfunded mandate is out of order, but may be overruled by a majority vote (Steytler et al., 2011: 11). The Congressional Budget Office's statement is part of the legislative process and any bill or joint resolution is out of order, unless there is a Congressional Budget Office mandate statement. Any member of Congress may raise a point of order stopping the bill, but such procedural device can be overridden by a simple majority in the committee before which it serves. Although this procedural device is weak, it at least forces the committee to consider the matter. The procedure discourages 
the imposition of unfunded mandates (Anderson \& Constantine, 2005:3). Posner (2007: 395) submits that UMRA promotes accountability which could embarrass mandate proponents and rally opponents.

Legislative awareness of unfunded mandates reduces the incidence of unfunded mandates. It enables affected governments to lobby against them, restraining federal government to some degree (Posner, 2007:390). It was reported that during the first decade of UMRA the Congressional Budget Office reviewed over 5200 bills, resolutions, and legislative proposals of which $12 \%$ contained an intergovernmental mandate (Steytler et al., 2011: 12). Of those nine percent would have exceeded the threshold, but in the end only five bills, where the cost of unfunded mandates exceeded the statutory threshold were passed.

South Africa has followed a somewhat similar approach in protecting local government from national and provincial mandates; on the basis of independent information, the national and provincial governments must consider their intended course of action (Steytler et al., 2011: 12). The Municipal Systems Act provides that an organ of state seeking to assign a function to local government or to a municipality must follow a detailed consultation procedure. It prescribes that a financial assessment must be solicited from government's chief intergovernmental fiscal advisory body, the Financial and Fiscal Commission. On the basis of the latter assessment consultations with organised local government and the key ministries must take place before the assigning legislation may be tabled in Parliament or the provincial legislature. In addition, the draft legislation must be accompanied by a memorandum, outlining a three-year projection of the financial implications, a disclosure of possible financial liabilities or risks and a plan for the funding of additional expenditure to be incurred by the relevant municipalities. Where the assignment fulfils the definition of an unfunded mandate (the imposition of a duty, falling outside of the municipality's original constitutional powers and having financial implications), the substantive requirements of "appropriate steps to ensure sufficient funding, and such capacity building initiatives as may be needed" become applicable (Steytler et al., 2011: 13). In 2003 further requisites were added when the Financial and Fiscal Commission Act, 1997 (Act of 1997) was amended. In terms of the Financial and Fiscal Commission Act, any organ of state seeking to assign a power or function to an organ of state in another sphere of government in terms of a law must notify the Financial and Fiscal Commission of the fiscal and financial implications of such assignment with regard to, the future division of revenue raised nationally; the fiscal power, fiscal capacity and efficiency of the relevant province or municipality; and any transfer of employees, assets and liabilities. These requisites of the Financial and Fiscal Commission Act are very desirable, but are 
yet to be realised. Unfunded mandates are a reality. There is no record of the statutory proceedings prescribed by the Financial and Fiscal Commission Act ever having been used in preparation of legislation or executive action that assigns functions to local government. For example, the Disaster Management Bill was passed in 2002 without following the said procedures even though it imposes duties on municipalities that fall outside of its constitutional mandate and have financial implications (Steytler et al., 2011: 13).

Australia also adopts an intergovernmental political route similar to United States. The Fåederal Parliamentary Committee viewed as part of the solution to cost shifting the definition of responsibilities of each sphere of government and how each sphere should be funded (Australian House of Representatives Economics Committee 2003:30). Local government must be involved in the negotiations before any shifts are made. A local government impact statement must be developed that identifies the financial impact of federal and state legislation.

\section{CONCLUSION}

The incidence of unfunded mandates reflects a power hierarchy. Unfunded mandates are a manifestation of the phenomenon of ruling from the centre. National government through various mechanisms imposes national mandates on provincial and local government, often at the expense of the latter. A lack of consensus on the definition of "unfunded mandates" implies that it is difficult to agree on the financial impact and extent of unfunded mandates. Despite being constitutionally permissible unfunded mandates run against the grain of democratic ideology. The principal critique is that unfunded mandates undercut the key constitutional notion of the different spheres of government being accountable to the public, because it confuses the public as to who does what.

There have been various responses to unfunded mandates. The measures for curbing or containing unfunded mandates are twofold, namely, radical intervention to impose a clear prohibition on the imposition of unfunded mandates similar to that done by the United States of America and Australia, and the more common approach is to admonish the transferring legislature or authority to stop, evaluate and consider before imposing a mandate. Further research in this area along the following lines is recommended (Steytler et al., 2011: 15). What are the drivers that prompt national/federal government to download some of its responsibilities? What circumstances whether constitutional or political facilitate unfunded mandates? Conversely, what circumstances inhibit cost shifting? Is it a question of clarity on the division of 
powers and functions, as suggested by Australians? Is it a matter of gaining access to another sphere of government's independent sources of revenue, and when there is none as in the case of South African provinces, there is no interest?

\section{List of References}

- Anderson, S. and Constantine, R. 2005. Unfunded mandates. Harvard Law School, Federal Budget Policy Seminar, Briefing paper 7.

- Australian House of Representatives Standing Committee on Economics, Finance and Public Administration. 2003. Rates and Taxes: A Fair Share for Local Government. Available at www.aph.gov.au/house/committee/efpa (Accessed 1 October 2011).

- Government of RSA v Grootboom 2000 (11) BCLR 883 (CC)

- Khumalo, B. and Mokate, R. 2007. Republic of South Africa. Shah, A. (ed). The Practice of Fiscal Federalism: Comparative Perspectives. McGill-Queens University Press: Montreal \& Kingston.

- McMillan, M.L. 2006. Municipal relations with the federal and provincial governments: a fiscal perspective. Robert, Y. \& Leprecth, C. (eds). Manada: the State of the Federation 2004: Municipal-Federal-Provincial Relations in Canada. McGill-Queens University Press: Montreal \& Kingston.

- Nel, E. and Binns, T. 2003. Putting 'developmental local government' into practice: the experience of South Africa's towns and cities. Urban Forum 14(2.3): Available at http://resources.metapress.com (accessed on 02 November 2011).

- Posner, P. 1997. Unfunded Mandate Reform Act of 1995. Publius, volume 27(2).

- Posner, P. 2007. The politics of coercive federalism in the Bush era. Publius, volume 37(3).

- Republic of South Africa. 1996. Constitution of the Republic of South Africa, 1996. Pretoria: Government Printer.

- Republic of South Africa. Department of Cooperative Governance and Traditional Affairs 2009. State of Local Government in South Africa: Overview Report. 2009. Pretoria: Government Printer. 
- Republic of South Africa. Division of Revenue Act. Pretoria: Government Printer.

- Republic of South Africa. 1997. Financial and Fiscal Commission Act, 1997. Pretoria: Government Printer.

- Republic of South Africa. 2011. Financial and Fiscal Service Commission: 2012/13 Submission for the Division of Revenue, 2011. Pretoria: Government Printer.

- Republic of South Africa. Intergovernmental Fiscal Relations Act. Pretoria: Government Printer.

- Republic of South Africa. Local Government Municipal Systems Act. Pretoria: Government Printer.

- Republic of South Africa. White Paper on Local Government, 1998. Pretoria: Government Printer.

- Sansom, G. 2009. Commonwealth of Australia. Steytler, N. (ed). Local Government and Metropolitan Regions in Federal Systems. McGill-Queens University Press: Montreal \& Kingston.

- Steytler, N. 2005. Local government in South Africa: Entrenching decentralised government. Johannesburg: Konrad-Adenauer-Stiftung.

- Steytler, N., De Visser, J. and Williams, R. 2011. Unfunded mandates: directing subnational governments. Community Law Centre. University of Western Cape. (accessed on 1 November 2011).

- Zimmerman, J.F. 1995. State Local Relations: A Partnership Approach. 2nd edition. Greenwood Publishing Group.

\section{AUTHOR'S CONTACT:}

\section{Basdeo}

University of South Africa

Email: mbasdeo@unisa.ac 